\title{
ANALISIS FAKTOR-FAKTOR YANG MEMPENGARUHI PERATAAN LABA
}

\author{
Dinda Nur Oktiviasari $^{1)^{*}}$, Dini Wahjoe Hapsari ${ }^{2)}$ \\ Fakultas Ekonomi dan Bisnis, Universitas Telkom \\ email: dnuroktiv@gmail.com \\ email: diniwahyu_2@yahoo.com
}

\begin{abstract}
Income smoothing is a part of income management strategy to produce income in a company with normal fluctuation. The freedom a company has to choosing its accounting method and regulations often becomes an opportunity for manager to commit self-interest actions. A company with normal income fluctuations will give it good reputation. So this phenomenon drives it to do income smoothing. The purpose of this research is to find the factors that can affect income smoothing practice. This research uses transportation companies listed on Indonesia Stock Exchange 2016-2018 with used quantitative method and sample its data with purposive sampling. The analysis techniques uses logistic regression SPSS.23.0. based on the result of this research, variables of managerial ownership, company size, and leverage simultaneously and significantly affect income smoothing with the value of 21,3\%. Partially, managerial ownership significantly affect income smoothing with positive direction towards income smoothing, while firm size and leverage don't affect income smoothing.
\end{abstract}

Keywords: Managerial Ownership, Firm Size, Leverage, Income Smoothing

\begin{abstract}
ABSTRAK
Perataan laba adalah bagian dari starategi manajemen laba agar perusahaan dapat menghasilkan laba dengan fluktuasi normal. Kebebasan perusahaan dalam memilih metode dan kebijakan akuntansi seringkali menjadi peluang bagi manajer untuk melakukan tindakan yang akan mementingkan dirinya sendiri. Perusahaan dengan fluktuasi laba yang normal akan memberi citra yang baik bagi perusahaan sehingga fenomena ini mendorong perusahaaan untuk melakukan perataan laba. Intensi dari penelitian ini adalah untuk mengetahui komponen yang diperkirakan mampu memberi dampak atas tindakan perataan laba. Sampel adalah perusahaan sub sektor transportasi yang tercatat di Bursa Efek Indonesia untuk periode 2016-2018 dengan menggunakan metode kuantitatif dan teknik pengambilan purposive sampling. Teknik analisis menggunakan regresi logistik memanfaatkan SPSS 23.0. Berdasar pada hasil analisis logistik, secara simultan variabel kepemilikan manajerial, ukuran perusahaan, dan leverage memiliki dampak terhadap perataan laba sebesar $21,3 \%$. Secara parsial hanya kepemilikan manajerial saja yang memiliki dampak signifikan dengan arah positif terhadap perataan laba, sedangkan ukuran perusahaan dan leverage tidak memiliki dampak pada perataan laba.
\end{abstract}

Kata Kunci: Kepemilikan Manajerial, Ukuran Perusahaan, Leverage, Perataan Laba 


\section{PENDAHULAN}

\section{Latar Belakang Penelitian}

Statement of Financial Accounting Concept No. 1 menjelaskan bahwa laporan keuangan menyajikan informasi yang dapat membantu stakeholder dalam mengambil sebuah keputusan rasional yang pada akhirnya akan memberikan manfaat untuk perusahaan. Dengan laporan keuangan, para pengguna laporan keuangan dapat memantau kondisi suatu perusahaan dan terdapat informasi penting yang seringkali menjadi pusat perhatian utama pengguna laporan keuangan adalah laba. Meningkatnya jumlah laba seringkali disimpulkan sebagai penilaian kinerja perusahaan selama periode tersebut (Yadiati \& Mubarok, 2017). Pada kenyataannya, masih terdapat manipulasi dalam mengelola laba perusahaan, salah satunya adalah dengan melakukan perataan laba yang menjadi salah satu bagian startegi dalam manajemn laba.

Manajemen laba yaitu kegiatan yang dilakukan seorang manajer perusahaan dalam mempengaruhi jumlah pendapatan pada waktu tertentu dengan memilih metode akuntansi yang sesuai dengan standar akuntansi atau dengan metode tertentu yang telah digunakan sebelumnya. Tindakan manajemen laba dilakukan untuk memperoleh motivasi dan tujuan yang ingin dicapai (Hery, 2015:51). Dalam Fiscal dan Stevany (2015:13) terdapat beberapa ragam manajemen laba yaitu taking a bath atau mandi besar Income minimization atau meminimumkan laba, income maximization atau memaksimalkan laba, dan income smoothing atau perataan laba. Praktik manajemen laba pada penelitian ini fokus pada perataan laba (income smoothing). Perataan laba atau income smoothing adalah tindakan mengurangi atau menambah laba dalam suatu periode sehingga jumlahnya menjadi lebih tinggi ataupun lebih rendah dari laba sesungguhnya (Ayunika \& Yadnyana, 2018:2404).
Perataan laba memiliki hubungan dengan teori keagenen. Dalam kegiatan operasi perusahaan seringkali terdapat pemisahan antara pemilik modal (principal) dan manajer (agent). Pemilik modal biasanya memberikan kebebasan kepada manajer dalam mengambil suatu keputusan sehingga manajer akan cenderung memiliki dan mengetahui informasi yang lengkap terkait perusahaan dibandingkan dengan pemilik. Salah satu usaha yang dilakukan adalah dengan mengelola laba dalam laporan keuangan menggunakan strategi perataan laba untuk mencapai tujuannya seperti menarik investor agar tertarik melakukan investasi pada perusahaan (Ramanuja \& Mertha, 2015:399). Terdapat beberapa komponen yang diperkirakan memiliki pengaruh pada tindakan perataan laba. komponenkomponen tersebut adalah kepemilikan manajerial, ukuran perusahaan, dan leverage.

Proporsi suatu saham yang dimiliki manajemen perusahaan disebut sebagai kepemilikan manajerial. Manajer berperan sebagai pemegang saham sehingga mereka berusaha untuk melakukan peningkatan atas nilai perusahaan yang cenderung diikuti dengan kekayaan pemegang saham yang meningkat pula. Persentase kepemilikan manajerial ini akan memberi dampak atas kegiatan pertaaan laba yang dilakukan karena mereka ikut menentukkan kebijakan dan mengambil keputusan terhadap kebijakan dan/ metode akuntansi (Sari \& Oktavia, 2019:79). Hal ini membuat seorang manajer lebih berhati-hati dalam memilih metode akuntansi agar dapat memberi hasil yang baik bagi para pemegang saham dan pemilik perusahaan. Hasil penelitian Nazira dan Ariani (2016:161) memiliki penjelasan bahwa kepemilikan manajerial memiliki dampak signifikan dan positif dengan perataan laba karena manajemen mendapatkan informasi perusahaan yang lebih lengkap sehingga menyebabkan 
manajemen melakukan perataan laba. Sebaliknya, menurut hasil penelitian Sari dan Oktavia (2019) tidak ada hubungan antara perataan laba dengan kepemilikan manajerial. Napitupulu et al (2018) memiliki penjelasan bahwa tidak ada dampak antara kepemilikan manajerial dan perataan laba karena para manajer dianggap mengutamakan hasil organisasi dan tidak termotivasi untuk mencapai tujuan-tujuan individu.

Faktor selanjutnya adalah ukuran perusahaan. Ukuran perusahaan digunakan untuk melihat besar kecilnya sebuah perusahaan yang salah satunya dapat diukur dengan total aset. Ukuran perusahaan dapat menjadi penilaian investor sebelum melakukan investasi. Penelitian ini menggunakan proksi total aset karena lebih stabil dalam mengklasifikasikan ukuran perusahaan dan tidak dipengaruhi permintaan atau penawaran. Perusahaan yang besar memiliki kecenderungan melakukan praktik income smoothing dengan tujuan mengurangi tingginya beban pajak dan mengurangi kemungkinan risiko yang akan terjadi akibat fluktuasi laba yang drastis (Ayunika \& Yadnyana, 2018:2409). Menurut hasil penelitian Oktaviasari et al (2018), ukuran perusahaan memiliki dampak yang signifikan dengan arah positif karena semakin besar ukuran perusahaa total aset yang dimiliki juga semakin besar dan total aset tersebut diperoleh dari modal yang besar sehingga perusahaan cenderung melakukan perataan laba untuk menarik investor. Di sisi lain, Djoko dan Tahu (2017) menyatakan ukuran perusahaan memiliki dampak yang signifikan dengan arah negatif karena besar kecilnya perusahaan dapat melakukan perataan laba untuk menghindari peraturan pemerintah.

Faktor yang terakhir adalah leverage. Rasio leverage atau solvabilitas dapat mengukur besarnya tingkat utang yang dimiliki perusahaan. besarnya kemampuan perusahaan dalam memenuhi semua kewajibannya juga dapat diukur dengan rasio ini. Leverage merupakan salah satu faktor yang menjadi pertimbangan para stakeholder karena dapat mencerminkan apakah perusahaan akan pailit atau tidak. Proksi debt to equity ratio digunakan dalam penelitian ini karena mampu memberi petunjuk sejauh mana modal yang dimiliki dapat memberikan jaminan atas seluruh utang yang dimiliki perusahaan. Selain itu, dengan menggunakan rasio ini akan mengetahui perbandingan antara modal pihak luar dan modal pihak pemilik. DER menjadi petunjuk kelayakan suatu kredit dan risiko keuangan kepada debitur (Hery, 2017:300). Menurut Zarnegar dan Hamidian (2016) leverage memiliki dampak signifikan dengan arah positif pada tindakan perataan laba karena tingginya tingkat leverage yang dimiliki perusahaan akan semakin memicu manajemen untuk melakukan perataan laba agar dapat meningkatkan kualitas pendapatan. Sedangkan hasil penelitian Sari et al (2018) mengatakan bahwa terdapat dampak yang signifikan dengan arah negatif antara leverage dan tindakan income smoothing karena perataan laba akan dilakukan manajer apabila tingkat leverage-nya rendah.

\section{Tujuan Penelitian}

1. Untuk menguji adanya hubungan antara variabel kepemilikan manajerial, ukuran perusahaan, dan leverage atas perbuatan perataan laba pada sub sektor transortasi secara simultan.

2. Untuk menguji dampak variabel kepemilikan manajerial, ukuran perusahaan, dan leverage atas perbuatan perataan laba pada sub sektor transportasi secara parsial.

\section{KAJIAN LITERATUR}

\section{Laporan Keuangan}

Statement of Financial Accounting Concept No.1 menjelaskan bahwa laporan keuangan dapat memberikan informasi 
yang membantu investor, kreditor, dan pengguna lainnya untuk mengambil sebuah keputusan rasional yang pada akhirnya akan memberikan manfaat untuk perusahaan. Posisi keuangan dan kinerja keuangan dalam laporan keuangan disusun secara runtut.

\section{Teori Keagenan}

Jensen dan Meckling (1976) pada (Ramanuja \& Mertha, 2015:399) menjelaskan bahwa teori keagenan merupakan pengendalian organisasi atau perusahaan dimana terdapat pemisahan tugas antara pemilik (principal) sebagai pihak yang menyediakan dana untuk kegiatan perusahaan dan manajemen (agent) sebagai pihak yang mengelola perusahaan sehingga menimbulkan adanya perbedaaan kepentingan.

\section{Perataan Laba}

Menurut Beidlment (1976) dalam Hery (2017:163), perataan laba adalah pengurangan fluktuasi laba secara sengaja agar berada pada tingkat normal bagi perusahaan. Investor memiliki ktertarikkan pada perusahaan dengan tingkat fluktuasi laba yang normal dari periode ke periode sehingga mereka akan melakukan penanaman modal pada perusahaan tersebut karena laba yang stabil dijadikan salah satu alat ukur bahwa perusahaan tersebut dalam kondisi yang baik sehingga manajer perusahaan akan membuat fluktuasi laba perusahaan terlihat normal dalam batas-batas yang diperbolehkan standar akuntansi yang berlaku (Andiani \& Astika, 2019:987). Penelitian ini menggunakan indeks eckel dalam menggolongkan perusahaan yang melakukan dan yang tidak melakukan perataan laba.

\section{Kepemilikan Manajerial}

Proporsi saham yang dimiliki manajemen perusahaan sehingga memiliki dua peran yaitu sebagai pengelola perusahaan dan sebagai pemegang saham disebut kepemilikan manajerial
(Napitupulu et al., 2018:6). Jumlah saham yang dimiliki manajer atau direksi dewan komisaris terhadap total saham yang beredar menjadi pengukur besarnya kepemilikan manajerial yang dimiliki manajemen perusahaan (Andiani \& Astika, 2019:994).

\section{Ukuran Perusahaan}

Ukuran perusahaan merupakan skala untuk membagi antara perusahaan besar dan kecilnya dengan total aktiva, penjualan log size, nilai pasar saham, dan kapasitas pasar (Djoko \& Tahu, 2017:40). Penelitian ini menggunakan total aset dimana Natural log (Ln) digunakan untuk meminimalisir fluktuasi data sehingga nilai variabel akan lebih sederhana tanpa adanya perubahan proporsi dari nilai yang sebenarnya (Andiani \& Astika, 2019:998).

\section{Leverage}

Rasio yang mampu mengukur seberapa besar utang yang dimiliki perusahaan atau seberapa besar perusahaan mampu memenuhi kewajiban baik jangka pendek atau jangka panjang disebut rasio leverage (Hery, 2017:295). Penelitian ini menggunakan DER sebagai proksi. DER dapat memberi informasi terkait jumlah modal yang disediakan oleh kreditor dibandingkan dengan jumlah modal yang berasal dari pemilik perusahaan.

\section{Kerangka Pemikiran dan Hipotesis}

i. Dampak Kepemilikan Manajerial Terhadap Perataan Laba

Berdasarkan penelitian Nazira dan Ariani (2016) dan penelitian Wijayanti dan Kurniawati (2019), menyatakan bahwa kepemilikan manajerial berdampak signifikan dengan arah positif pada perataan laba.

ii. Dampak Ukuran Perusahaan Terhadap Perataan Laba

Berdasarkan penelitian Tria, et al (2018) dan penelitian Wijayanti dan Kurniawati (2019) menyatakan bahwa ukuran perusahaan berdampak 
signifikan dengan arah positif pada perataan laba.

iii. Dampak Leverage terhadap Perataan

Laba

Berdasarkan penelitian Zarnegar dan Hamidian (2016) dan penelitian Ramanuja dan Mertha (2015) menyatakan bahwa leverage berdampak signifikan dengan arah positif pada perataan laba.

\section{Hipotesis}

$\mathbf{H}_{\mathbf{1}}$ : Kepemilikan manajerial, ukuran perusahaan, dan leverage memiliki pengaruh simultan terhadap perataan laba.

$\mathbf{H}_{2}$ : Kepemilikan manajerial berdampak dengan arah positif terhadap perataan laba.

$\mathbf{H}_{3}$ : Ukuran perusahaan berdampak dengan arah positif terhadap perataan laba.

$\mathbf{H}_{4}$ : Leverage berdampak dengan arah positif terhadap perataan laba.

\section{METODE PENELITIAN}

\section{Desain Penelitian}

Penelitian yang dilakukan bertujuan agar dapat mengetahui dan mampu menjelaskan karakteristik dari variabelvariabel pada situasi (Hermawan \& Yusran, 2017:5). Metodologi dalam penelitian ini adalah metodologi kuantitatif. Strategi penelitiannya yaitu studi kasus. Menggunakan Unit analisis berupa kelompok yaitu perusahaan transportasi yang merupakkan salah satu sub sektor di BEI dan menggunakan data panel yaitu pada tahun 2016-2018. Keterlibatan peneliti dalam penelitian adalah intervensi minimal. Latar penelitian adalah noncontrived setting. Waktu pelaksanaan penlitian adalah cross sectional, artinya data terdiri dari beberapa subjek pada waktu tertentu (Indriantoro \& Supomo, 2018:93).

\section{Sumber dan Cara Pengumpulan Data}

Sumber data yang dikumpulkan dalam penelitian ini adalah data sekunder. Data sekunder yaitu informasi yang berasal dari sumber yang telah dibuat sebelumnya (Sekaran \& Roger, 2017:130). Penelitian ini menggunakan data yang berkaitan dengan kepemilikan manajerial, ukuran perusahaan, dan leverage yang diperoleh dari laporan tahunan perusahaan sub sektor transportasi. Selain itu, menggunakan informasi yang didapat dari jurnal, skripsi, dan buku-buku yang dapat mendukung penelitian.

\section{Populasi dan Sampel}

Populasi adalah perusahaan sub sektor transportasi yang tercatat di BEI pada periode 2016-2018. Purposive sampling digunakan sebagai pemilihan sampel. Perusahaan yang memenuhi kriteria adalah sebanyak 45 sampel yang terdiri dari 15 perusahan dimana penelitian ini dilakukan selama tiga tahun. Namun setelah diuji, terdapat 1 data outlier sehingga total sampel menjadi 44.

\section{Teknik Analisis Data}

Teknik analisis kuantitatif dengan teknik perhitungan statistik deskriptif digunakan dalam penelitian ini. Untuk menganalisis data penelitian memanfaatkan software SPSS 23.0, sedangkan metode analisisnya menggunakan metode analisis regresi.

Pengolahan data menggunakan analisis regresi logistik digunakan sebab variabel terikatnya bersifat dummy atau nominal. Persamaan regresi logistik yang akan dalam penelitian ini adalah (Ghozali, 2018:325):

$L N \frac{\mathrm{PL}}{1-\mathrm{PL}}=\alpha+\beta 1 K M+\beta 2 L N T A+\beta 3 D E R+\varepsilon$

Beberapa tahap pengujian hipotesis yang dilakukan adalah sebagai berikut:

\section{Statistik Deskriptif}

Statistik deskriptif merupakan statistik yang dapat membantu mengatahui hasil analisis data menggunakan gambaran data yang sudah terkumpul sebagaimana adanya tanpa maksud membuat 
kesimpulan atau generalisasi (Sugiyono, 2015:254).

\section{Menilai Kelayakan Model Regresi}

Penilaian kelayakan regresi menggunakan Hosmer and Lemeshow's Goodness of Fit Test. Model ini dapat menguji hipotesis nol bahwa data empiris sesuai dengan model sehingga bisa dikatakan fit apabila hasilnya menunjukkan nilai sama dengan atau kurang dari 0,05 maka hipotesis 0 ditolak. Sedangkan jika hasilnya menunjukkan nilai lebih besar dari 0,05 maka hipotesis 0 diterima yang artinya model dapat memprediksi nilai observasi karena telah sesuai dengan data.

\section{Menilai Model Fit (-2LogL)}

Uji fit adalah model untuk menilai apakah hipotesis telah fit dengan data atau tidak. Output SPSS akan menghasilkan dua nilai yaitu nilai -2LogL pertama yang hanya terdiri dari konstanta saja dan hasil kedua yang telah memasukkan variabel bebas atau independen (Ghozali, 2018:332).

\section{Pengujian Simultan (Uji F)}

Dampak dari variabel independen terhadap variabel dependen secara simultan dapat diketahui dengan uji simultan. Pengujian terdapat pada tabel Omnimbus Tests of Model Coefficients menggunakan logit regresi dengan metode enter tingkat signifikansi $(\alpha)$ 5\%. Apabila signifikansi hasilnya lebih dari 0,05 maka $\mathrm{H}_{1}$ ditolak sedangkan jika tingkat signifikansinya kurang dari 0,05 maka $\mathrm{H}_{1}$ diterima (Ghozali, 2018:179).

\section{Koefisien Determinasi (R2)}

Besar nilai koefisien determinasi dapat dilihat nilai Nagelkerke's $R$ Square. Persentase Nagelkerke's $R$ Square yang semakin besar menunjukkan kemampuan variabel independen dalam menjelaskan variabel dependennya semakin baik pula (Ghozali, 2018:333).

\section{Pengujian Parsial (Uji t)}

Uji parsial dilakukan untuk melihat pengaruh variabel independen terhadap variabel dependen. Hasilnya dapat dilihat pada tabel Wald Statistic (Ghozali, 2018:235). Apabila tingkat signifikansi hasilnya lebih dari 0,05 maka $\mathrm{H}_{\mathrm{a}}$ ditolak yang artinya variabel independen tidak berpengaruh terhadap variabel dependen. Sedangkan jika tingkat signifikansi kurang dari 0,05 maka $\mathrm{H}_{\mathrm{a}}$ diterima yang artinya variabel independen berpengaruh terhadap variabel dependen.

\section{HASIL DAN PEMBAHASAN}

\section{Statistik Deskriptif}

Tabel 1. Statistik Deskriptif

\begin{tabular}{|l|r|r|r|r|r|}
\hline & & & & & \multicolumn{1}{c|}{ Std. } \\
& $\mathrm{N}$ & Minimum & Maximum & \multicolumn{1}{c|}{ Mean } & Deviation \\
\hline X1 & 44 & .0000 & .6803 & .110604 & .1812957 \\
X2 & 44 & 26.4271 & 31.4087 & 28.263718 & 1.3511591 \\
X3 & 44 & .0810 & 3.8030 & 1.268154 & .8445004 \\
Valid & 44 & & & & \\
N & & & & & \\
\hline
\end{tabular}

Sumber: Data diolah, 2020

Dalam Tabel 1, variabel kepemilikan manajerial memiliki nilai minimium 0000 dan nilai maksimum 0,6803 . Nilai mean sebesar 0,110604 dan nilai standar deviasi sebesar 0,1812957.

Variabel ukuran perusahaan (LnTA) memiliki nilai minimum 26,4271 dan nilai maksimum 31,4087. Nilai rata-rata sebesar 28,263718 dan nilai standar deviasi adalah 1,3511591 .

Variabel leverage (DER) memiliki nilai minimum 0,081 dan nilai maksimum 3,8030. Nilai rata-rata sebesar 1,268154 dan nilai standar deviasi sebesar 0,8445004 .

Tabel 2. Statistik Deskriptif Perataan Laba

\begin{tabular}{|l|c|c|}
\hline & $\begin{array}{c}\text { Jumlah } \\
\text { Perusahaan }\end{array}$ & $\%$ \\
\hline $\begin{array}{l}\text { 1= Melakukan Perataan } \\
\text { Laba }\end{array}$ & 18 & $40,9 \%$ \\
\hline $\begin{array}{l}\text { 0= Tidak Melakukan } \\
\text { Perataan Laba }\end{array}$ & 26 & $59,1 \%$ \\
\hline \multicolumn{1}{|c|}{ Total } & 44 & $100 \%$ \\
\hline
\end{tabular}

Sumber: Data diolah, 2020

Berdasarkan Tabel 2 dan hasil perhitungan indeks eckel, dari 44 sampel 
yang digunakan terdapat 18 atau $40,9 \%$ tergolong melakukan perataan laba dan 26 atau $59,1 \%$ sampel tergolong tidak melakukan perataan laba. Data ini menunjukkan bahwa perusahaanperusahaan sub sektor transportasi sebagian besar tidak melakukan perataan laba.

\section{Menilai Kelayakan Model Regresi}

Tabel 3. Hosmer and Lemeshow Test

\begin{tabular}{|l|r|r|r|}
\hline Step & Chi-square & df & Sig. \\
\hline 1 & 12.012 & & 8 \\
\hline
\end{tabular}

Sumber: Data diolah, 2020

Tabel di atas merupakan hasil dari pengujian Hosmer and Lemeshow Test, diperoleh tingkat signifikan 0,151. Dalam penelitian ini $\mathrm{H}_{0}$ akan diterima dan tidak dapat ditolak atau tingkat signifikansi hitung hasilnya lebih besar dari 0,05, sehingga $\mathrm{H}_{0}$ diterima karena tingkat signifikansi lebih besar dari 0,05 (0,151 > $0,05)$ yang artinya model dapat diterima karena sudah cocok dengan data observasinya.

\section{Menilai Model Fit (-2LogL)}

Tabel 4. Overall Model Fit

\begin{tabular}{|l|l|}
\hline \multicolumn{2}{|c|}{ Overall Model Fit (-2LogL) } \\
\hline -2LogL Block Number $=0$ & Nilai 59,534 \\
\hline -2LogL Block Number $=1$ & Nilai 51,532 \\
\hline
\end{tabular}

Sumber: Data diolah, 2020

Tabel Overall Model Fit di atas menunjukkan hasil nilai -2LogL awal (Block Number $=0$ ) menunjukkan nilai yang jumlahnya sebesar 59,534, sedangkan nilai -2LogL berikutnya (Block Number = 1) menghasilkan nilai yang lebih kecil yaitu 51,532. Terjadi penurunan nilai antara nilai $-2 \operatorname{LogL}$ awal dengan nilai -2LogL berikutnya sehingga model layak digunkan untuk analisis selanjutnya.

\section{Pengujian Simultan (Uji F)}

Tabel 5. Omnimbus Tests of Model Coefficient

\begin{tabular}{|rl|r|r|r|}
\hline & & & \\
& & Chi-square & df & Sig. \\
\hline Step 1 & Step & 8.002 & 3 & .046 \\
& Block & 8.002 & 3 & .046 \\
& Model & 8.002 & 3 & .046 \\
\hline
\end{tabular}

Sumber: Data diolah, 2020

Berdasarkan hasil pengujian regresi logistik dalam tabel 5, diperoleh nilai chisquare sebesar 8,002, degree of freedom $=$ 3 dan tingkat dari signifikansi yang diperoleh sebesar 0,046 ( $p$-value < 005), maka $\mathrm{H}_{1}$ diterima. Artinya, kepemilikan manajerial, ukuran perusahaan, dan leverage secara simultan memiliki pengaruh terhadap perataan laba yang ada di perusahaan transportasi yang merupakan salah satu sub sektor di BEI pada tahun 2016-2018.

\section{Koefisien Determinasi (R2)}

Tabel 6. Model Summary

\begin{tabular}{|l|r|r|r|}
\hline Step & $\begin{array}{c}-2 \text { Log } \\
\text { likelihood }\end{array}$ & $\begin{array}{c}\text { Cox \& Snell } \\
\text { R Square }\end{array}$ & $\begin{array}{c}\text { Nagelkerke R } \\
\text { Square }\end{array}$ \\
\hline 1 & $51.532^{\mathrm{a}}$ & .166 & .224 \\
\hline
\end{tabular}

Sumber: Data diolah, 2020

Pada tabel model summary ini diperoleh hasil pengujian koefisien determinasi atau pengujian yang dapat mengukur kemampuan variabel independen yang digunakan dalam model memiliki pengarus terhadap variabel dependen. Berdasarkan tabel tersebut dapat diketahui nilai Nagelkerke $R$ Square yang dihasilkan yaitu 0,224 . Ini artinya, variabel-variabel independen yang digunakan dalam penelitian ini mampu mempengaruhi sebesar $22,4 \%$ terhadap variabel dependen.

\section{Pengujian Parsial (Uji t)}

Pengujian parsial berguna untuk memperoleh informasi terkait bagaimana dampak kepemilikan manajerial, ukuran perusahaan, dan leverage terhadap perataan laba dengan menguji koefisien regresi dengan melihat dan membandingkan antara nilai signifikansi dengan tingakat signifikansi. 
Tabel 7. Variables in the Equation

\begin{tabular}{|r|r|r|r|r|r|r|r|r|}
\hline & \multirow{2}{*}{ B } & S.E. & Wald & \multirow{2}{*}{ df } & \multirow{2}{*}{ Sig } & \multirow{2}{*}{$\operatorname{Exp}(\mathrm{B})$} & \multicolumn{2}{|c|}{ 95\% C.I.for EXP(B) } \\
\cline { 8 - 10 } & & & & & & & Lower & Upper \\
\hline $\mathrm{X} 1$ & 5.914 & 2.819 & 4.400 & 1 & .036 & 370.055 & 1.474 & 92884.682 \\
\hline $\mathrm{X} 2$ & -.295 & .337 & .768 & 1 & .381 & .744 & .385 & 1.441 \\
\hline $\mathrm{X} 3$ & -.018 & .487 & .001 & 1 & .971 & .982 & .378 & 2.552 \\
\hline Constanta & 7.371 & 9.117 & .654 & 1 & .419 & 1589.775 & & \\
\hline
\end{tabular}

Sumber: Data diolah, 2020

Berdasarkan hasil pengujian pada tabel uji parsal, maka persamaan model regresi logistik yang diperoleh adalah:

$L N \frac{\mathrm{PL}}{1-\mathrm{PL}}=7,371+5,914 K M-0,295 \operatorname{LnTA}-0,018 D E R$

Berdasarkan hasil pada Tabel Uji t, nilai dari koefisien regresi kepemilikan manajerial sebesar 5,914 dengan taraf signifikan kepemilikan manajerial adalah 0,036 dan nilai ini lebih kecil dari tingkat signifikansi $(\alpha)=0,05$. Sehingga dapat diketahui bahwa variabel kepemilikan manajerial memiliki dampak dengan arah positif terhadap perataan laba pada perusahaan sub sektor transportasi. Perusahaan dengan jumlah kepemilikan manajemen yang tinggi memiliki dorongan yang tinggi pula dalam melakukan tindakan perataan laba. Hal ini dapat dilakukan karena seorang manajer mendapatkan akses yang mudah dalam mendapatkan informasi perusahaan. Selain itu, manajemen ikut memberikan keputusan kebijakan dan metode akuntansi yang akan digunakan perusahaan. Hasil dari penelitian memiliki arah yang sama dengan dengan hasil penelitian Nazira dan Ariani (2016) dan hasil penelitian Wijayanti dan Kurniawati (2019).

Variabel kedua yaitu ukuran perusahaan meperoleh nilai koefisien regresi sebesar 0,295 dan taraf signifikansi yaitu 0,381 lebih besar dari signifikansi $(\alpha)=0,05$. Dari hasil ini maka dapat diketahui bahwa tidak terdapat dampak antara variabel ukuran perusahaan dan perataan laba. Hal ini karena perusahaan yang tergolong besar akan mendapatkan pengawasan yang ketat dan pemeriksaan yang ketat dari pemerintah dan stakeholder lainnya terkait laporan keuangan maupun audit yang dilakukan secara kompeten maka perusahaan besar memiliki tuntutan yang kuat untuk menghasilkan laporan keuangan yang dapat dipercaya sehingga mampu menekan tindakan manajer untuk tidak melakukan perataan laba. Hasil dari penelitian ini searah dengan penelitian yang dilakukan oleh Obaidat (2017) dan hasil penelitian Indrawan et al (2018).

Hasil yang diperoleh uji t menunjukkan variabel leverage memiliki nilai koefisien regresi sebesar $-0,018$ dan taraf signifikan sebesar 0,971. Nilai ini lebih besar dari signifikansi $(\alpha)=0,05$ yang artinya variabel leverage tidak memiliki dampak terhadap perataan laba. Hal ini karena pendanaan kegiatan operasional perusahaan tidak hanya bersumber dari utang yang berasal dari kreditor. Selain itu, pembayaran atas utang juga akan menimbulkan biaya lainnya seperti bunga yang wajib dibayar. Hal ini membuat perusahaan lebih memilih alternatif lain untuk memenuhi kebutuhan dananya. Penelitian ini memiliki hasil yang searah dengan penelitian yang dilakukan Wijayanti dan Kurniawati (2016) dan penelitian Sari dan Oktavia (2019).

\section{KESIMPULAN DAN SARAN}

\section{Kesimpulan}

a) Secara simultan kepemilikan manajerial, ukuran perusahaan (LnTA), dan leverage (DER) signifikan mempengaruhi perataan laba.

b) Secara parsial kepemilikan manajerial signifikan memiliki dampak terhadap perataan laba pada sub sektor 
transportasi yang tercatat di Bursa Efek Indonesia tahun 2016-2018.

c) Secara parsial ukuran perusahaan dengan proksi total aset tidak memiliki dampak terhadap perataan laba pada perusahaan sub sektor transportasi yang tercatat di Bursa Efek Indonesia tahun 2016-2018.

d) Secara parsial leverage dengan proksi DER tidak memiliki dampak terhadap perataan laba pada sub sektor transportasi yang tercatat di Bursa Efek Indonesia tahun 2016-2018.

\section{Saran}

a) Penelitian ini diharapkan mampu memberi pengetahuan dan wawasan bagi para akademisi.

b) Untuk peneliti selanjutnya diharapkan mengganti sektor penelitian dan memperbanyak atau menggunkan variabel independen lain.

c) Bagi manajemen perusahaan terutama dengan jumlah kepemilikan manajerial yang tinggi diharapkan dapat meningkatkan kinerja perusahaan dengan pengawasannya dalam kegiatan usaha.

d) Bagi stakeholder diharapkan penelitian ini mampu memberi informasi sebelum melakukan investasi pada perusahaan dan lebih memilih berinvestasi pada perusahaan yang memiliki jumlah kepemilikan manajerial yang rendah sehingga peluang melakukan perataan labanya rendah.

\section{UCAPAN TERIMAKASIH}

Penulis dapat menyelesaikan penelitian ini tidak lepas dari dukungan dan doa keluarga, bantuan dan dukungan lain yang diperoleh dari Universitas Telkom selaku institusi tempat penulis menimba ilmu, para dosen Fakultas Ekonomi dan Bisnis yang telah membagikan ilmu bermanfaat untuk penulis, Ibu Dini Wahjoe Hapsari selaku pembimbing penulis selama penelitian, dan pihak-pihak lain yang telah memberikan kritik, saran, dan motivasi untuk penulis.

\section{DAFTAR PUSTAKA}

Andiani, A. A. S. N., \& Astika, I. B. P. (2019). Pengaruh Struktur Kepemilikan dan Ukuran Perusahaan Pada Praktik Perataan Laba. E-Jurnal Akuntansi, 27(2), 987-998.

Ayunika, N. P. N., \& Yadnyana, I. K. (2018). Pengaruh Ukuran Perusahaan, Profitabilitasdan Financial Leverage Terhadap Praktik Perataan Laba Pada Perusahaan Manufaktur. E-Jurnal Akuntansi Universitas Udayana, 25(3), 2409.

Djoko, D., \& Tahu, G. P. (2017). Pengaruh Ukuran Perusahaan, Leverage, ROA, dan Net Profit Margin terhadap Praktik Perataan Laba pada Perusahaan Manufaktur yang Terdaftar di Bursa Efek Indonesia Periode 2012-2014. Jurnal Ekonomi Dan Pariwisata, 12(1), 40-44.

Ghozali, I. (2018). Aplikasi Analisis Multivariate dengan Program IBM SPSS 25. Universitas Diponegoro.

Hermawan, A., \& Yusran, Hu. L. (2017). Penelitian Bisnis Pendekatan Kuantitatif. Kencana.

Hery. (2015). Analisis Kinerja Manajemen. Gasindo.

Hery. (2017). Teori Akuntansi. Grasindo.

Indrawan, V., Agoes, S., Pangaribuan, H., \& Papoola, O. M. J. (2018). The Impact of Audit Committee, Firm Size, Profitability, and Leverage on Income Smoothing. Indian-Pacific Journal of Accounting and Finance (IPJAF), 2(1), 61-74.

Indriantoro, N., \& Supomo, B. (2018). Metodologi Penelitian Bisnis. Andi.

Napitupulu, J., Nugroho, P. S., \& Kurniasari, D. (2018). Pengaruh Cash Holding, Profitabilitas, Reputasi Auditor, dan Komponen Good 
Corporate Governance Terhadap

Perataan Laba (Studi Pada

Perusahaan Manufaktur yang

Terdaftar di BEI Periode 2013-2016).

Prima Ekonomika, 9(2), 1-16.

Nazira, C. F., \& Ariani, N. E. (2016).

Pengaruh Jenis Industri, Kepemilikan

Manajerial, Operating Profit Margin, dan Dividend Payout Ratio Terhadap Perataan Laba pada Perusahaan Yang Terdaftar di Bursa Efek Indonesia Tahun 2012-2014. Jurnal Ilmiah Mahasiswa Ekonomi Akuntansi, 1(1), 161.

Obaidat, A. N. (2017). Income Smoothing Behavior at the Times of Political Crises. International Journal of Academic Research in Accounting, Finance and Management Sciences, 7(2), 10.

Oktaviasari, T., Miqdad, M., \& Effendi, R. (2018). Pengaruh Profitabilitas, Ukuran Perusahaan, dan Leverage terhadap Perataan Laba pada Perusahaan Manufaktur di BEI. EJournal Ekonomi Bisnis Dan Akuntansi, 5(1), 87.

Ramanuja, I. G. V., \& Mertha, I. M. (2015). Pengaruh Varian Nilai Saham, Kepemilikan Publik, Der Dan Profitabilitas, Pada Perataan Laba. EJurnal Akuntansi Universitas Udayana, 10(2), 399-410.

Sari, I. P., \& Oktavia, F. (2019). Pengaruh Return On Equity, Risiko Keuangan, Ukuran Perusahaan dan Kepemilikan Manajerial terhadap Income Smoothing. Menara Ilmu, 13(2), 7980.

Sekaran, U., \& Roger, B. (2017). Metode Penelitian untuk Bisnis (1st ed.). Salemba Empat.

Sugiyono. (2015). Metode Penelitian Kuantitatif, Kualitatif dan Kombinasi (Mixed Methods). Alfabeta.

Wijayanti, R., \& Kurniawati, L. (2019).

Pengaruh Ukuran Perusahaan,

Profitabilitas, Leverage, dan Struktur
Kepemilikan terhadap Income Smoothing. The 9th University Colloqium 2019, 9(3), 321-326.

Yadiati, W., \& Mubarok, A. (2017). Kualitas Pelaporan Keuangan.

Kencana. 